\title{
EFFECT OF SUMMER IRRIGATION ON POPULATION DYNAMICS AND REPRODUCTIVE STATUS OF ADULT SITONA LEPIDUS IN THE WAIKATO
}

\author{
B. WILLOUGHBY and S. HARDWICK
}

\author{
Agresearch, Ruakura Research Centre, Private Bag 3123, Hamilton
}

\begin{abstract}
Populations of adult Sitona lepidus were sampled from five irrigated and five non-irrigated dairy pastures in the Waikato from November 1998 to April 1999. Under irrigated conditions, the presence of a second peak of adults with significantly more tenerals present provides evidence of a second generation over the summer months. The importance of the role of moisture in the development of S. lepidus was further demonstrated by the differences in the development of eggs in the calyces of sexually mature females. Egg development was significantly greater in females in irrigated pastures. Onset of rain after a dry period resulted in rapid egg development in females in non-irrigated pastures. These findings explain why the summer dry La Nina weather conditions in the Waikato led to farmer observations of a reduced impact of $S$. lepidus on clovers in Waikato pastures in 1998 and 1999.
\end{abstract}

Keywords: Sitona lepidus, reproduction, population, summer rainfall, irrigation.

\section{INTRODUCTION}

The clover root weevil (Sitona lepidus Gyllenhal (Coleoptera: Curculionidae) was first recorded in New Zealand in 1996 (Barratt et al. 1996). Subsequent examination of stored weevil samples revealed that it had been present in the Waikato in 1995 (Barker et al. 1996) and probably considerably earlier since infestations already covered some 200,000 ha of improved pastureland.

Population studies in the Waikato in 1996 and 1997 indicated that S. lepidus can complete two generations per year (Willoughby and Addison 1997). Addison et al. (1998) reported significant differences in the populations of S. lepidus between the summers of 1997 and 1998. Field populations of adult S. lepidus in the Waikato in 1997 had high levels of reproductive females in early summer and were followed by a summer larval generation. However, in the 1998 summer, non-reproductive females predominated and a summer generation of larvae did not eventuate. Soil moisture and/ or rainfall were implicated in the variation in the reproductive state of the insect and the consequent observed population differences.

This paper reports on the populations and reproductive condition of S. lepidus adults in five irrigated and five non-irrigated paddocks over the summer months of 1999 in the Waikato.

\section{MATERIALS AND METHODS}

Adult S. lepidus populations were sampled weekly from five irrigated and five non-irrigated paddocks on the Dairy Research Corporation farm in the Waikato from November 1998 to March 1999. The sampling was along a $30 \mathrm{~m}$ transect using a suction apparatus (modified Homelite HB $180 \mathrm{~V}$ Blower Vac). To ensure that 20 adult S. lepidus were taken from each paddock at each sampling date, a second suction sample of weevils was taken. The sampling period was extended to fortnightly intervals from mid March to April 1999. The pastures were predominately perennial rye grass (Lolium perenne) and white clover (Trifolium repens) with secondary 
pasture species of annual grasses. The paddocks were grazed by dairy cows at a stocking rate of 3.2 cows per ha, on a 35 - 40 day rotation. The soils were predominantly a light sandy loam (Horitui sandy loam) on a flat aspect. Paddocks in the irrigated treatment received the equivalent of $32 \mathrm{~mm}$ of rainfall every week, applied by overhead sprinkler during the trial period.

S. lepidus adults collected were counted, sorted and stored at $-20^{\circ} \mathrm{C}$ in sealed containers for up to three months before their reproductive development was assessed as described previously (Willoughby and Addison 1997).

The adult count data was $\log _{e}(n+1)$ transformed to normalise the variance before being analysed in Genstat using a t-test. The percentage of the population that was teneral was calculated for each sampling date and the data analysed in Genstat using a generalised linear model. An estimate of the number of teneral adults per $30 \mathrm{~m}$ suction sample was then calculated using the percentage data and count data from each sampling date. This data was then rank transformed and analysed using a t-test. The percentage of sexually mature females with eggs in their calyces, as a percentage of all sexually mature females was also calculated for each sampling date and the data analysed in Genstat using a generalised linear model.

\section{RESULTS}

Higher numbers of adult S. lepidus were recovered from the irrigated than nonirrigated paddocks, although at times these differences were not significant (Fig. 1). Populations of adult weevils in both the irrigated and non-irrigated pastures were similar, peaking at 20 and 11 adults $/ 30 \mathrm{~m}$ sample, respectively in early January. The number of adults found in both the irrigated and non-irrigated paddocks then declined to $3-5$ adults $/ 30 \mathrm{~m}$ sample in early February 1999. Populations in the non-irrigated paddocks remained around 2-3 adults $/ 30 \mathrm{~m}$ sample for the remainder of the study period. However, the populations measured from the irrigated paddocks significantly increased $(\mathrm{P}<0.01)$ with a second peak of abundance of 29 adults $/ 30 \mathrm{~m}$ sample occurring in early March 1999. The populations in the irrigated paddocks remained significantly greater $(\mathrm{P}<0.01)$ than those in the non-irrigated pastures from the mid February 1999 until the final sample in early April (Fig. 1).

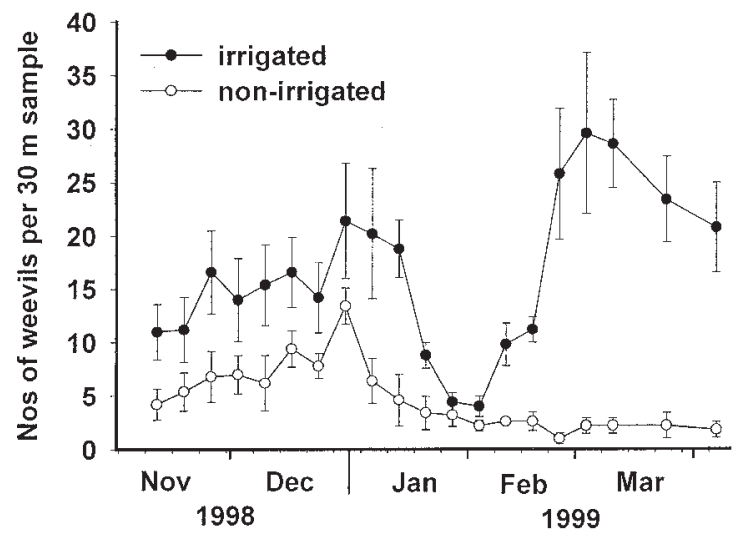

FIGURE 1: Mean number of adult $S$. lepidus $( \pm \mathrm{SE})$ found in $30 \mathrm{~m}$ suction samples taken from irrigated and non-irrigated pastures over the 1998/99 summer period. 
Dissection of the adult $S$. lepidus revealed that in mid November, approximately $60 \%$ were teneral, with no development of the reproductive system (Fig. 2a). There was no difference $(\mathrm{P}>0.05)$ in the percentage of teneral adults in samples from irrigated and non-irrigated paddocks. The percentage of teneral adults in samples then decreased to very low levels in both irrigated and non-irrigated paddocks by mid January 1999. However, while the proportion of teneral adults in samples from nonirrigated paddocks was low in the latter half of the sampling period (mid January-early March 1999), there was a trend for an increase in the proportion from irrigated paddocks (Fig. 2a). While these proportions of teneral adults were low $(10-15 \%)$, they were significantly different from late January to early March (Fig. 2a).
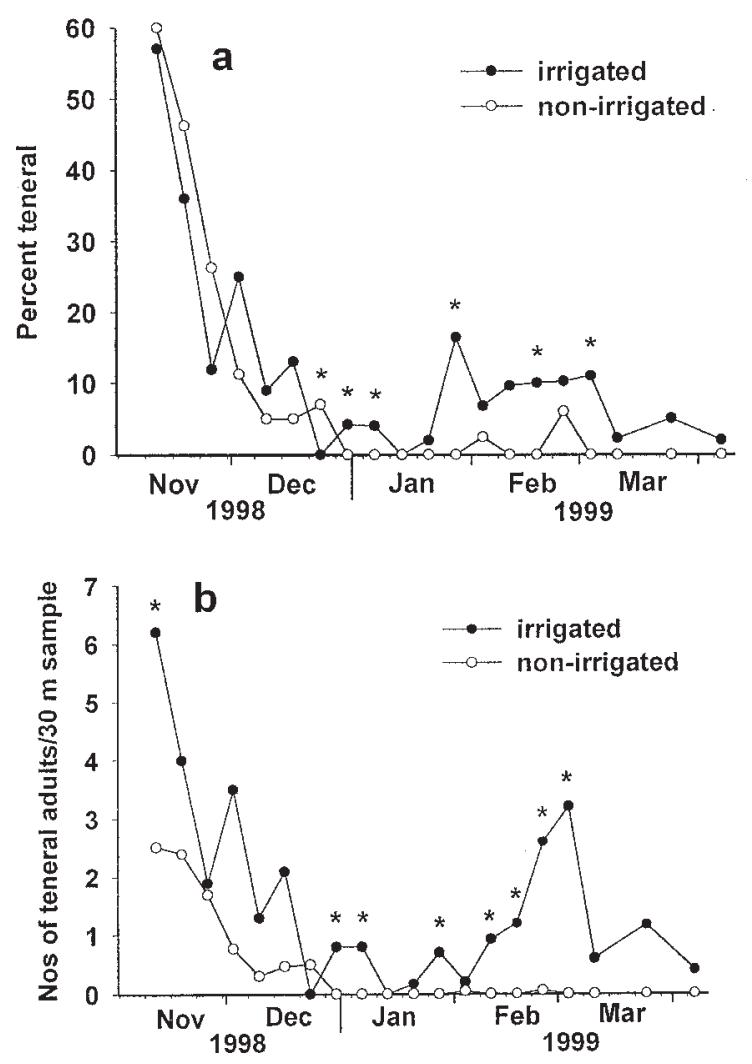

FIGURE 2: a) Teneral adults as a percentage of adult population over the summer of 1998/99. b) Teneral adults $/ 30 \mathrm{~m}$ sample over the summer of 1998/99 $(*=$ significant difference $(P<0.05)$ between irrigated and non-irrigated paddocks).

In mid November 1998, estimated numbers of teneral adults/30 m sample were significantly different $(\mathrm{P}<0.05)$ between the irrigated and non-irrigated treatments at 6 and 2.5 respectively per $30 \mathrm{~m}$ sample (Fig. $2 \mathrm{~b}$ ). The numbers declined through November and December 1998 in both irrigated and non-irrigated pastures. From the end of December until March, 1999 teneral adults were virtually absent in the non- 
irrigated paddocks. However, in the irrigated paddocks, a further two peaks in the number of teneral adults occurred in late December and through January to early March. Over this period, there were significantly more $(\mathrm{P}<0.05)$ teneral adults in the irrigated paddocks, compared with non-irrigated (Fig. 2b).

Reproductive development of S. lepidus females varied between the irrigated and non-irrigated pastures. This variation was significant $(\mathrm{P}<0.05)$ over the late December/ January period. Dissections of female weevils revealed that the percentage of sexually mature females that had eggs in their calyces in non-irrigated paddocks was 55-70\% compared with $90-98 \%$ for those from irrigated paddocks (Fig. 3a). This reduction in the percentage of females with eggs in their calyces appeared to be associated with a dry period which occurred between $9^{\text {th }}$ December 1998 to $14^{\text {th }}$ January 1999 during which only $12.2 \mathrm{~mm}$ of rain fell (Fig. 3b). The proportion of females with eggs in their calyces appeared to increase in response to the occurrence of rainfall in the third and fourth weeks of January 1999 (Fig. 3). A trend for the proportion of sexually mature females with eggs in the calyces to decline over the February 1999 period when only $12.4 \mathrm{~mm}$ of rain fell also occurred; however, this decline was not significant (Fig. 3).

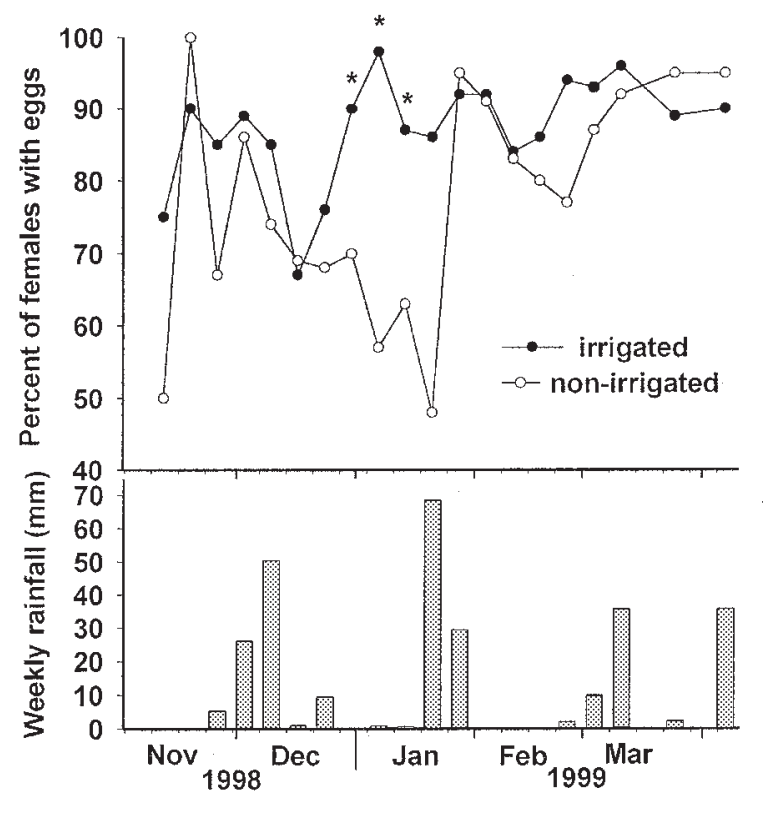

FIGURE 3: a) Percentage of sexually mature females with eggs in their calyces over the summer of $1998 / 99$. b) Weekly rainfall $(\mathrm{mm} /$ week) at Ruakura Research Centre $(*=$ significant difference $P<0.05$ between irrigated and non-irrigated paddocks).

\section{DISCUSSION}

A second peak of $S$. lepidus adult emergence observed from the irrigated pastures in late February 1999, with little corresponding emergence from the non-irrigated pastures, constitutes strong circumstantial evidence for the presence of a second generation under conditions of adequate moisture. Summer (1998/99) temperatures in the Waikato averaged $19.4^{\circ} \mathrm{C}$ (range mean min of $12.1^{\circ} \mathrm{C}-$ mean max of $27.0^{\circ} \mathrm{C}$ ) (Anon. 1998, 1999). At $20^{\circ} \mathrm{C} \mathrm{S}$. lepidus is capable of development from egg to adult 
within 80 days (P. Gerard unpubl. data). The significantly greater proportion of teneral adults within this second population peak also supports the contention. In the Waikato, the importance of moisture over the summer period in the instigation of a second generation of $S$. lepidus is evidenced by the role played by irrigation. Further supporting evidence comes from the apparent response in sexual maturation by S. lepidus adults in non-irrigated pastures to the rainfall events in mid January.

As conditions dried in the non-irrigated pastures, the presence of an increasing proportion of sexually mature females with no eggs in their calyces supports previous evidence of drought induced reduction in oviposition (Addison et al. 1998). The absence of a second generation is therefore likely to be partially responsible for previously differences in summer S. lepidus populations observed by Addison et al. 1998 in the Waikato in 1996 and 1997.

As a consequence of the dry summers of 1997/98 and 1998/99, damage to pasture caused by S. lepidus in the Waikato has declined and clover vigour has increased. However, when moist (La Nina) summer weather patterns return, S. lepidus numbers will likely increase in the Waikato causing pasture damage levels as observed in the summers of 1995/96 and 1996/97.

\section{ACKNOWLEDGEMENTS}

Thanks to Catherine Cameron for meteorological data, Neil Cox for statistical analysis, Paul Addison, Fiona Kettlewell and Tina Eden for technical assistance.

\section{REFERENCES}

Addison, P.J., Willoughby, B.E., Hardwick, S. and Gerard, P.J., 1998. Clover root weevil: Observations on differences between 1997 and 1998 summer populations in the Waikato. Proc. 51st N.Z. Plant Prot. Conf:: 1-4.

Anon., 1998, 1999. New Zealand Climate Digest: December 1998, January 1999, February 1999.

Barker, G.M., Addison, P.J., Firth, A.C. and Barratt, B.I.P., 1996. Sitona lepidus Gyllenhal (Coleoptera: Curculionidae) newly established in New Zealand: assesment of distribution in the North Island. Proc. 49th N.Z. Plant Prot. Conf.: 266-269.

Barratt, B.I.P., Barker, G.M., Addison, P.J., 1996. Sitona lepidus Gyllenhal (Coleoptera: Curculionidae), a potential clover pest new to New Zealand. N.Z. Entomol. 19: 23-30.

Willoughby, B. and Addison, P.J., 1997. Clover root weevil (Sitona lepidus)-a threat to the sustainability of white clover in New Zealand pastoral systems? Pp 26-30. In: Soil Invertebrates in 1997. P.G. Allsopp, D.J. Rogers and L.N. Robertson (Eds): Bureau of Sugar Experimental Stations. 